\title{
Antioxidant Profile of Buckwheat Honey from the Republic of Moldova
}

\author{
MIRUNA DRAGANESCU ${ }^{1}$, CATERINA DUMITRU ${ }^{1 *}$, LILIANA BAROIU ${ }^{1}$, \\ ALINA IANCU ${ }^{1 *}$, CAMELIA VIZIREANU ${ }^{2}$, MANUELA ARBUNE ${ }^{1}$, ADRIAN BEZNEA ${ }^{1}$ \\ 1 "Dunarea de Jos" University from Galati, Faculty of Medicine, 47 Domneasca Str., 800008, Galati, Romania \\ ${ }^{2}$ Dunarea de Jos" University from Galati, Faculty of Food Science and Engineering, 111 Domneasca Str., 800201, Galati, \\ Romania
}

\begin{abstract}
The honey is a natural substance, whose therapeutic qualities have been developed in parallel with human evolution. Its antioxidant and antiinflammatory properties are due to the polyphenolic compounds. The purpose of this study is to identify and quantify the phenolic compounds and the FTIR spectrum from buckwheat honey from the Balti region, Republic of Moldova. The radical scavenging activity of honey was $83 \%$ in the DPPH・ reaction system. Phenolic compounds from honey were identified by HPLC-MS method, the significant concentrations being lignans, catechins, isorhamnetin, rutin, apigenin and luteolin. FTIR analysis revealed both the carbohydrate profile in buckwheat honey and the presence of active compounds.
\end{abstract}

Keywords: buckwheat honey, polyphenols, flavonoids, antioxidant activity, FTIR spectrum

\section{Introduction}

Since ancient times, honey has been used not only as a food, but also as a main ingredient, in both alternative medicine for treating gastrointestinal, respiratory, dermatological and also in cosmetology. The honey is produced by Apis mellifera bees by mixing nectar from plants with their own substances, followed by maturation in honeycombs [1].

The honey, with a percentage of $95 \%$ carbohydrates, is an important product through the content of biologically active products. The most important factors in determining the composition of honey are represented by the botanical origin, geographical location, time and conditions of harvest [2].

Buckwheat is a plant with an old tradition of cultivation due to the nutritional content and especially of the antioxidant compounds present. At the same time, buckwheat is used to support honey production, being considered one of the best plants to obtain it.

Buckwheat (Fagopyrum esculentum Moench) of the family Polygonaceae, is a pseudocereal that arrived in Europe through Russia at the end of the Middle Ages. It was cultivated to supplement the harvest of basic cereals, especially in regions with poor sandy, clay or acidic soil, being a very resistant plant, which is why insecticides are not needed. Buckwheat shows a flowering period of 3 to 6 weeks and a complete maturation in 11-12 weeks [3]. Plants produce many white flowers and bloom in late summer when other plants no longer bloom [4]. Therefore, buckwheat honey is a very important source of nectar for bees, being a major product of the cultivation of this plant. It is estimated that 1 ha of land cultivated with buckwheat can produce between 125-300 kg honey [5].

Many studies have shown that dark color honey is richer in phenolic compounds, which would imply a higher antioxidant activity [6,7].

Buckwheat honey, with a dark color and a distinctive flavor, is a unique food product, containing bioactive compounds derived from bees and plants, rich in flavonoids, with beneficial effects on the body. Studies have shown that, due to the high content of phenolic compounds, buckwheat honey exhibits antibacterial activity against Staphylococcus aureus and Micrococcus luteus on varicose ulcer wounds [8].Brudzinsky and colab. showed in a 2012 study published in Frontiers in Microbiology [9] the bactericidal effect of buckwheat on E coli and B. subtilis cells. The latest studies [10,11] have

*email:dumitrukati@yahoo.com, iancualina.2003@yahoo.com 
demonstrated the antibacterial potential of the buckwheat honey in nosocomial infections including Clostridium difficile, due to the high concentration of phenolic compounds and the synergistic contributions of saturated sugars $(\sim 80 \%)$

The rutin, a flavonol with cytoprotective, vasoprotective, anticarcinogenic, neuroprotective and cardioprotective properties $[10,13]$ is present in buckwheat in larger quantities than in other plants. The ability of honey to scavenge the superoxide anion is used both in the food industry and in the pharmaceutical industry.

The purpose of this study is to identify and quantify the main polyphenolic compounds present in buckwheat honey from the Balti, a region of Republic of Moldova, in 2012. This study is the first to perform an analysis of flavonoid compounds present in the buckwheat honey from the Balti region, Moldova.

The infrared spectroscopic analysis (FTIR,) was used to determine the specific spectral fingerprint, thus being able to construct a model capable of predicting the physico-chemical parameters according to the obtained results. Also, by analyzing the FTIR spectrum, one can appreciate the antioxidant capacity of the respective honey $[14,15]$.

\section{Materials and methods}

\subsection{Material}

The study was carried out on buckwheat honey purchased from beekeepers from Balti region, the Republic of Moldova, in 2012.

\subsection{Chemicals and reagents}

All standards used were purchased from Sigma Aldrich GmbH (Steinheim, Germany). Organic solvents methanol and acetonitrile, HPLC grade, were purchased from Merck Romania; formic acid (98\%), Tris(hydroxymethyl)aminomethane, acetic acid, ammonium acetate, ammonia, ultrapure water were purchased from Merck (Romania). Solid phase extraction (SPE) StrataX $200 \mathrm{mg}$ 6m/L cartridges were purchased from Phenomenex (Romania). Absolute ethanol, Folin-Ciocalteu phenol reagent, $\mathrm{AlCl}_{3}$, were purchased from Merck Romania. All other chemicals and reagents were of analytical grade.

\subsection{Analysis of total polyphenols content}

The total polyphenol content (TPC) was determined by spectrophotometric analysis, using T80 UV/VIS spectrophotometer and gallic acid as standard, according to the method described by the International Organization for Standardization (ISO, 14502-1) [16] . Honey (5 g) was diluted to 50 $\mathrm{mL}$ with distilled water. One millilitre of this honey solution was mixed with $5 \mathrm{~mL}$ of Folin-Ciocalteu reagent $(1: 10)$ and $4.0 \mathrm{~mL}$ of sodium carbonate solution $(7.5 \% \mathrm{w} / \mathrm{v})$. After keeping the tubes at room temperature for $60 \mathrm{~min}$, the absorbance at the wavelength $\lambda=765 \mathrm{~nm}$ was read using a UV-Vis spectrophotometer (T80 UV/ VIS spectrophotometer) relative to a control sample (in which $1 \mathrm{~mL}$ of the extract was replaced). with $1 \mathrm{~mL}$ of distilled water). The total polyphenol content was expressed as gallic acid equivalents (GAE) in $\mathrm{mg} / 100 \mathrm{~g}$ of plant material. The TPC was determined by interpolation of the sample absorbance against a calibration curve built with gallic acid standards (10, 20, 30, 40, 50 $\mu \mathrm{g} / \mathrm{mL}$ in $10 \%$ ethanol) and expressed as milligrams of gallic acid equivalents (GAE) per $100 \mathrm{mg}$ of honey (mg GAE/100 mg), using the calibration curve, $y=0.071 x+0.006, R^{2}=0.0092$

\subsection{Analysis of total flavonoid content}

The total flavonoid content (TFC) was determined by spectrophotometric analysis, using T80 UV/VIS spectrophotometer and quercetin as standard, according to the method [17] based on the formation of a yellow flavonoid-aluminum complex and its absorbance reading at $430 \mathrm{~nm}$. To $1 \mathrm{~mL}$ aqueous extract was added $1 \mathrm{~mL} 2 \% \mathrm{AlCl}_{3}$ atentie $(2.5 \% \mathrm{w} / \mathrm{v}), 2 \mathrm{~mL} \mathrm{CH}_{3} \mathrm{COOH}(10 \% \mathrm{w} / \mathrm{v})$ and ethanol $(70 \% \mathrm{w} / \mathrm{v})$ to a volume of $10 \mathrm{~mL}$. After $30 \mathrm{~min}$ the absorbance at the wavelength $\lambda=430 \mathrm{~nm}$ 
is being read. Flavonoid content was expressed as quercetin equivalents, and calculated using the standard curve plotted on the concentration range 10 and $50 \mu \mathrm{g} / \mathrm{mL}$ of quercetin, using the calibration curve, $\mathrm{y}=0.0045 \mathrm{x}+0.0062, \mathrm{R}^{2}=0.00978$. All the analysis were performed in duplicate.

\subsection{Determination of antioxidant activity by DPPH method}

The determination of antioxidant activity by the DPPH method was performed according to the protocol of Brand - Williams with some modifications [18]. The stock solution was obtained by dissolving $0.024 \mathrm{~g}$ DPPH in $100 \mathrm{~mL}$ methanol, was kept in a refrigerator until further use. Prior to analysis, a dilution of 1:10 with methanol was prepared from the stock solution. For analysis, $3 \mathrm{~mL}$ of DPPH working solution was added to $0.1 \mathrm{~mL}$ extract $(1 \mathrm{mg} / \mathrm{mL})$ or the standard solution. The absorbance was measured at $517 \mathrm{~nm}$ for a period of $30 \mathrm{~min}$. The absorbance was read at the T80 UV / VIS spectrophotometer, the color of the solution being proportional to the antioxidant concentration.

The percentage of DPPH inhibition was measured according to the following equation:

$$
\operatorname{RSA}(\mathrm{DPPH} \%)=\left[\left(\mathrm{A}_{\text {control }}-\mathrm{A}_{\text {sample }}\right) / \mathrm{A}_{\text {control }}\right] \times 100
$$

where $\mathrm{A}_{\text {control }}$ is the absorbance of the control sample. The control contained $100 \mu \mathrm{L}$ methanol in place of the sample and $\mathrm{A}_{\text {sample }}$ is the absorbance of the analyzed extracts.

\subsection{Sample preparation}

To a gram of honey, there were added $5 \mathrm{~mL}$ of extraction solvent, $1 \% \mathrm{HCl}$ in methanol. The samples were vortexed for $5 \mathrm{~min}$, sonicated for $30 \mathrm{~min}$, centrifuged for $15 \mathrm{~min}$ at $3000 \mathrm{rpm}$ and then filtered. The obtained extracts were stored in the freezer and were used to determine total polyphenols and total flavonoids. The extract prepared for the determination of total polyphenols was filtered through a $0.45 \mu \mathrm{m}$ filter and injected into the HPLC-DAD-MS Agilent 1200 system.

\subsection{Analysis of phenolic compounds by HPLC}

HPLC-MS analysis of the phenolic compounds by the HPLC-DAD-MS method was performed using the Agilent 1200 HPLC system with DAD detector coupled with Agilent 6110 single quadrupole MS detector. Positive ionization ESI mode was used.

The separation of the phenolic compounds was carried out on a chromatographic column as it follows: Eclipse XDB C18, size 4.6x $150 \mathrm{~mm}, 5 \mu \mathrm{m}$, Agilent, at temperature: $25^{\circ} \mathrm{C}$.

The mobile phase consisted of: Solvent A: Water + 0.1\% Acetic acid / Acetonitrile (99/1) v / v

Solvent B: Acetonitrile $+0.1 \%$ acetic acid. The gradient used corresponds to the first 2 min mobile phase A 95\%, B 5\% followed by a linear increase of solvent B to $40 \%$ until min 18, linear growth of phase B up to $90 \%$ the next $12 \mathrm{~min}$, maintenance for $2 \mathrm{~min}$ and return to $95 \% \mathrm{~A}$ and $5 \% \mathrm{~B}$ in the next minute with holding for column balancing $5 \mathrm{~min}$. Total analysis time - $30 \mathrm{~min}$ with a mobile phase flow rate of $0.5 \mathrm{~mL} / \mathrm{min}$

Monitored wavelengths: $280 \mathrm{~nm}, 340 \mathrm{~nm}$

For MS analysis, the positive ESI ionization mode was used. The ionization parameters were: Capillary voltage: $3000 \mathrm{~V}$; Temperature: $350^{\circ} \mathrm{C}$, Nitrogen flow rate: $81 / \mathrm{min}$.

Data acquisition was done in full scan mode in the mass range m / z: 100-1000. The identification of phenolic compounds in samples was done by comparing the retention times, the UV and mass spectra with those of the injected standards.

\subsection{FTIR analysis}

FTIR analysis was performed for honey, using the Magna-IR Spectrometer 350 equipment (Nicolet Instrument Corporation, USA), by recording spectra from 4000 to $700 \mathrm{~cm}^{-1}$ with a spectral resolution of $1 \mathrm{~cm}^{-1}$, using the technique of Total Reflection Attenuation (ATR - Total Reflectance Attenuator) 


\section{Results and discussions}

TPC of buckwheat honey was $55 \pm 0.6 \mathrm{mg}$ GAE / $100 \mathrm{~g}$ sample. TPC is lower than Chinese honey (149.8 mg GAE / 100g [19], 169 mg GAE / 100g [20], or Polish honey (100 mgGAE / 100g [21] 87.28 $\mathrm{mg} \mathrm{GAE} / 100 \mathrm{~g})[22]$.

TFC of buckwheat honey was $47 \pm 0.8 \mathrm{mg}$ QE / $100 \mathrm{~g}$ sample. TFC of buckwheat honey was about 10 times higher than Polish buckwheat honey (3.23 mg QE/100 g of honey)[23]. Compared to other varieties of honey, buckwheat has a much higher TFC.

The antioxidant activity of buckwheat honey was conducted by DPPH assay, which is one of the most stable free radical. The antioxidant activity of buckwheat honey (expressed as \% of inhibition) was $83 \%$. The obtained result can be compared to the study of [24], where the DPPH radical reaction system measured was $87.28 \%$ [22]. Compared to the current study, Dzugan and colab. [25]. described similar values (76.42-82.41\%) for Polish buckwheat honey.

Table 1 shows TPC, TFC of honey in our study compared to other honey varieties.

Tabelul 1.TPC, TFC of honey in our study compared to other honey varieties

\begin{tabular}{|c|c|c|}
\hline Honey & $\begin{array}{c}\text { TPC } \\
\text { mg GE / 100 g } \\
\text { honey }\end{array}$ & $\begin{array}{c}\text { TFC } \\
\text { mg QE / 100 g honey }\end{array}$ \\
\hline Buckwheat (our study) & $55 \pm 0.6$ & $47 \pm 0.8$ \\
\hline Dill [26] & $32.5 \pm 1.1$ & $4.1 \pm 0.2$ \\
\hline Parsley [26] & $28.3 \pm 0.9$ & $3.6 \pm 0.2$ \\
\hline Orange Bossom [26] & $19.1 \pm 0.1$ & $1.7 \pm 0.1$ \\
\hline Rubus [27] & $33.9 \pm 15.4$ & $1.4 \pm 0.3$ \\
\hline Wild rose [28] & $11.6 \pm 0.19$ & $0.16 \pm 0.03$ \\
\hline Eucalyptus [28] & $17.5 \pm 1.16$ & $4.13 \pm 1.03$ \\
\hline Orange bossom [28] & $7.45 \pm 0.66$ & $1.73 \pm 0.39$ \\
\hline Lavender [29] & $53.39 \pm 23.34$ & $2.20 \pm 1.54$ \\
\hline Astragalus [29] & $43.63 \pm 20.66$ & $0.86 \pm 0.49$ \\
\hline
\end{tabular}

Following the HPLC-MS analysis performed in the present study, the following flavonoid compounds were identified Table 2, Figure 1.

Table 2.Retention time, wavelength characteristic of maximum absorption and ion monitored in ms for phenolic compounds identified in samples

\begin{tabular}{|c|c|c|c|c|}
\hline $\begin{array}{c}\text { No. } \\
\text { Pea } \\
\mathbf{k}\end{array}$ & $\begin{array}{c}\text { Retention } \\
\text { time } \\
\mathbf{t}_{\mathbf{R}}(\mathbf{m i n})\end{array}$ & $\begin{array}{c}{[\mathbf{M}-\mathbf{H}]^{+}} \\
(\mathbf{m} / \mathbf{z})\end{array}$ & $\begin{array}{c}\mathbf{U V} \boldsymbol{\lambda}_{\max } \\
(\mathbf{n m})\end{array}$ \\
\hline $\mathbf{1}$ & 3,2 & $\mathbf{3 7 9}, 363$ & 280 & Hidroxisecolariciresinol (lignan) \\
\hline $\mathbf{2}$ & 4,7 & $\mathbf{3 0 7}, 202$ & 280 & Epigallocatechina (EGC) \\
\hline $\mathbf{3}$ & 5,5 & $\mathbf{4 5 9}, 202$ & 280 & Epigallocatechingallat (EGCG) \\
\hline $\mathbf{4}$ & 7,0 & $\mathbf{4 5 9 , 2 0 2}$ & 280 & Coumestroc (isoflavonoid) \\
\hline $\mathbf{5}$ & 9,4 & $\mathbf{2 6 9}, 183$ & 240,300 & Catechin \\
\hline $\mathbf{6}$ & 12,1 & $\mathbf{2 9 1}, 202$ & 280 & Secolariciresinol (lignan) \\
\hline $\mathbf{7}$ & 12,9 & $\mathbf{3 6 3}, 247,163$ & 280 & \\
\hline
\end{tabular}




\begin{tabular}{|c|c|c|c|c|}
\hline $\mathbf{8}$ & 14,0 & $\mathbf{4 4 9}, 287$ & 270,350 & Orientin \\
\hline $\mathbf{9}$ & 14,5 & $\mathbf{4 4 9 , 2 8 7}$ & 270,350 & Isoorientin \\
\hline $\mathbf{1 0}$ & 15,4 & $\mathbf{4 3 3}, 271$ & 270,340 & Rutin \\
\hline $\mathbf{1 1}$ & 16,1 & $\mathbf{6 1 1}, 475,303$ & 250,360 & Isorhamnetin glucuronid \\
\hline $\mathbf{1 2}$ & 16,4 & $\mathbf{4 9 3}, 475,317$ & 250,320 & Quercetin arabinosid \\
\hline $\mathbf{1 3}$ & 17,7 & $\mathbf{4 3 5}, 303$ & 270,330 & Quercetin \\
\hline $\mathbf{1 4}$ & 18,1 & $\mathbf{4 4 9 , 4 3 3 , 3 0 3}$ & 270,330 & Isorhamnetin \\
\hline $\mathbf{1 5}$ & 21,9 & $\mathbf{3 0 3}$ & 260,370 & Luteolin \\
\hline $\mathbf{1 6}$ & 23,4 & $\mathbf{3 1 7}$ & 260,370 & Apigenin \\
\hline $\mathbf{1 7}$ & 24,3 & $\mathbf{2 8 7}$ & 240,330 & 240,320 \\
\hline $\mathbf{1 8}$ & 25,2 & $\mathbf{2 7 1}$ & Quercitrin$)$ \\
\hline
\end{tabular}

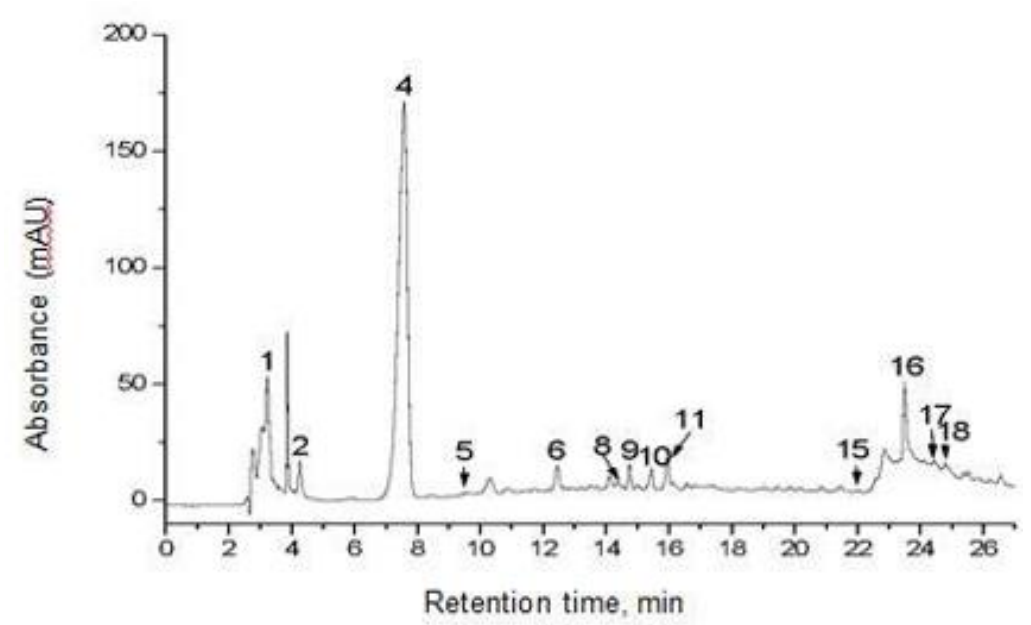

Figure 1. $280 \mathrm{~nm}$

chromatogram peak

1-hydroxisecoisolariciresinol;

2-EGC; 4-GCG; 5-coumestrol;

6-catechin; 8-orientin;

9-isoorientin; 10-vitexin;

11-rutin; 15-quercetin,

16-isorhamnetin; 17-luteolin; 18-apigenin

Flavonoid quantification, Table 2, was performed based on the calibration curves drawn for each compound, Table 4 . The linearity of the method was demonstrated by the correlation coefficient that was for all the compounds analyzed between 0.99-1.

Table 3. Amount of flavonoids excreted in $\mu \mathrm{g} / \mathrm{g}$ sample

\begin{tabular}{|c|c|}
\hline Compound & $\boldsymbol{\mu g} / \mathbf{g}$ sample \\
\hline Hydroxisecoisolariciresinol & 97.40 \\
\hline EGC & 28.82 \\
\hline GCG & 594.46 \\
\hline Coumestrol & 4.60 \\
\hline Catechin & 18.59 \\
\hline Orientin & 10.40 \\
\hline Isoorientin & 11.94 \\
\hline Vitexin & 12.96 \\
\hline Quercetin & 1.10 \\
\hline Rutin & 19.44 \\
\hline Isorhamnetin & 131.17 \\
\hline
\end{tabular}




\begin{tabular}{|c|c|}
\hline Luteolin & 17.39 \\
\hline Apigenin & 18.76 \\
\hline
\end{tabular}

Table 4. Analytical performances of the method used for the quantification of individual flavonoid compound in honey

\begin{tabular}{|c|c|c|c|c|c|c|c|}
\hline \multirow[t]{2}{*}{ Validation parameters } & \multirow[t]{2}{*}{ Calibration equation } & \multirow[t]{2}{*}{$\mathbf{R}$} & \multirow{2}{*}{$\begin{array}{l}\text { LOD } \\
\mu g / g\end{array}$} & \multirow{2}{*}{$\begin{array}{l}\text { LOQ } \\
\mu g / g\end{array}$} & \multicolumn{2}{|c|}{ Precision (RDS, \%) } & \multirow{2}{*}{$\begin{array}{c}\text { Repetability } \\
\text { (RSD, \%) }\end{array}$} \\
\hline & & & & & intra-day & inter-day & \\
\hline Hidroxisecolariciresinol & $Y=11307 X+4493$ & 0.992 & 10.40 & 31.52 & 3.15 & 2.85 & 4.31 \\
\hline Epigallocatechina & $Y=11198 X+2849$ & 0.993 & 9.65 & 29.24 & 2.49 & 2.62 & 3.56 \\
\hline Epigallocatechingallat & $Y=3240 X-3511$ & 0.990 & 16.84 & 51.03 & 2.36 & 4.1 & 2.82 \\
\hline Gallocatechingallat & $Y=8671 X+2133$ & 0.994 & 18.21 & 55.18 & 1.89 & 2.36 & 4.27 \\
\hline Coumestrol & $Y=4735 X-2771$ & 0.995 & 0.82 & 2.48 & 2.23 & 3.04 & 3.95 \\
\hline Catechin & $\mathrm{Y}=1435 \mathrm{X}+305$ & 0.993 & 0.35 & 1.06 & 2.81 & 5.01 & 3.97 \\
\hline Secolariciresinol & $Y=1001 X-261$ & 0.998 & 1.65 & 5.00 & 2.65 & 3.25 & 4.04 \\
\hline Orientin & $Y=5100 X-4382$ & 0.998 & 2.31 & 7.00 & 3.45 & 3.89 & 5.01 \\
\hline Isoorientin & $Y=1294 X+525$ & 0.991 & 1.15 & 3.48 & 4.25 & 3.87 & 3.26 \\
\hline Vitexin & $Y=7555 X+2105$ & 0.998 & 2.47 & 7.48 & 3.29 & 4.32 & 3.57 \\
\hline Rutin & $Y=3022 X+156$ & 0.996 & 11.02 & 33.39 & 2.47 & 2.65 & 2.12 \\
\hline Isorhamnetin glucuronid & $Y=43279 X-1900$ & 0.996 & 3.45 & 10.45 & 2.43 & 3.16 & 5.04 \\
\hline Quercetin arabinosid & $Y=74639 X+2708$ & 0.994 & 8.31 & 25.18 & 1.26 & 2.08 & 3.44 \\
\hline Quercetin ramnosid & $Y=54104 X-5319$ & 0.991 & 9.03 & 27.36 & 3.11 & 3.15 & 2.27 \\
\hline Quercetin & $Y=53615 X-1292$ & 0.992 & 0.32 & 0.97 & 4.48 & 1.58 & 32.23 \\
\hline Isorhamnetin & $Y=69535 X-2208$ & 0.993 & 10.5 & 31.82 & 3.04 & 4.28 & 4.98 \\
\hline Luteolin & $\mathrm{Y}=14473 \mathrm{X}-4389$ & 0.995 & 4.10 & 12.42 & 2.97 & 3.18 & 3.61 \\
\hline Apigenin & $Y=24574 X+5685$ & 0.995 & 6.02 & 18.24 & 3.65 & 3.78 & 3.18 \\
\hline
\end{tabular}

Note: LOD, limit of detection; LOQ, limit of quantification.

The floral origin of nectar and pollen determines the content in phenolic compounds and consequently the bioactive properties of bee honey [30].

It is observed that the highest concentrations were obtained for GCG, EGC, flavonoids that have not been found in other types of buckwheat honey [19, 28]. Small amounts of catechins have been identified in heather honey $(23.07 \mu \mathrm{g} / \mathrm{g})$, lavender honey $(7.85 \mu \mathrm{g} / \mathrm{g})$, chaste tree $(1.87 \mu \mathrm{g} / \mathrm{g})$ [29]. This fact shows the possibility of buckwheat honey to be used in different nutraceuticals, knowing the role of catechins in inhibiting bacterial growth [31], the effect of hypocholesterolemia [32, 33, 34] by lowering cholesterol absorption and increasing fecal excretion and decreasing ROS induced cytotoxicity through intracellular scavenging [35].

Also, a significant concentration of isorhamnetin was identified $(131.17 \mu \mathrm{g} / \mathrm{g}$ sample $)$ in buckwheat honey. The presence of isorhamnetin, but in much smaller amounts, has been reported by Can [29],in honey acacia (3.25 $\mu \mathrm{g} / \mathrm{g}$ sample) and by Yao in eucalyptus honey (4-1.1 $\mu \mathrm{g} / \mathrm{g}$ sample) [36]. Studies have shown that isorhamnetin exerts strong anti-inflammatory and immunosuppressive activities, and can be used to treat both chronic inflammation and autoimmune diseases [37, 38, 39].This honey contains a number of flavonoids. For example, quercetin, orientin, isoorientin, vitexin, luteolin, apigenin, isorhamnetin are also present in other varieties [19, 28, 29, 40].

Of these, the highest concentration is isorhamnetin, of $131.17 \mu \mathrm{g} / \mathrm{g}$ sample, which may confer particular properties, as this flavonoid has important antioxidant, antibacterial, antiinflammatory, hepatoprotective, cardioprotective [41] activities. Rutin was found at a concentration of $19.44 \mu \mathrm{g} / \mathrm{g}$ sample. In other types of buckwheat honey this flavonoid has not been identified [19, 21, 42]. 
It was also observed that other flavonoids such as chrysin, kaempferol, myricetin, galangin [43, $44,45]$ were not detected in buckwheat honey from the present study.

Of the total phenolic compounds, $80 \%$ are flavonoids, the rest being mainly lignans, namely hydroxisecoisolariciresinol, in a surprisingly high concentration, 97,40 $\mu \mathrm{g} / \mathrm{g}$ sample and coumestrol, $4,60 \mu \mathrm{g} / \mathrm{g}$ sample. The level of the main phenolic acids (caffeic, p-hydroxybenzoic, ferulic ) present in other studies [20, 21, 42 ] are in insignificant quantities. Although in a small amount, coumestrol may exert its stimulation effects on the estrogen receptor, inhibiting adipocyte differentiation [45], known that after pass through the gastric passage, the structure of coumestrol does not change [46, 47], and may also act at small concentrations.

ATR-FTIR infrared spectroscopy is a rapid method used for the qualitative characterization of honey. The analysis of the spectrometric fingerprint of honey by determining the chemical bonds specific to the characteristic chemical compounds [48].

In Figure 2 and Table 5 are presented to the FTIR absorption bands, together with the corresponding vibration allocation for buckwheat honey.

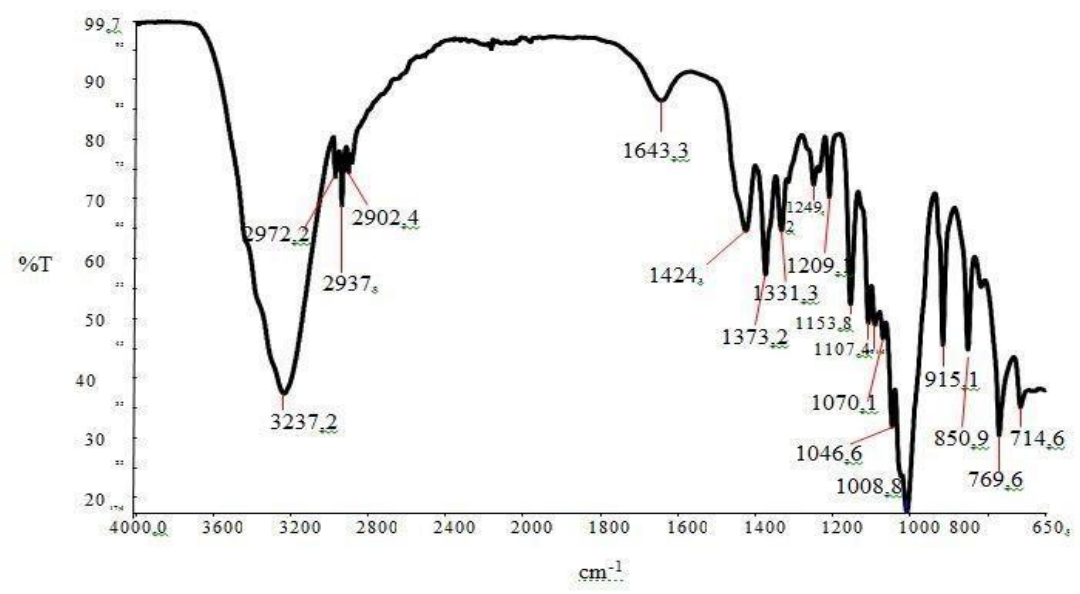

Figure. 2. The absorption bands of the FT-IR spectrum of buckwheat honey

The spectral domains most often used in honey analysis are those within the fingerprint region, $700-1500 \mathrm{~cm}^{-1}$, which corresponds to the absorption of monosaccharides, such as glucose and fructose and disaccharides, sucrose $[49,50]$ as well as the region $2500-4000 \mathrm{~cm}^{-1}$, which characterizes the antioxidant capacity [51].

Table 5.Allocation of the corresponding vibrations for the honey of spectrally made $700-4000 \mathrm{~cm}^{-1}$

\begin{tabular}{|c|c|}
\hline Position of the band $\left(\mathrm{cm}^{-1}\right)$ & Type and origin of vibration \\
\hline 769,6 & \multirow{3}{*}{$\delta(\mathrm{C}-\mathrm{H})$ from the structure of carbohydrates } \\
\hline 850,9 & \\
\hline 915,1 & \\
\hline 1008,8 & \multirow[t]{2}{*}{$v(\mathrm{C}-\mathrm{O})$ in the $(\mathrm{C}-\mathrm{OH})$ group or $v(\mathrm{C}-\mathrm{C})$ group in the structure of carbohydrates } \\
\hline 1046 & \\
\hline 1070,1 & \multirow[t]{2}{*}{$v(\mathrm{C}-\mathrm{O})$ in the $(\mathrm{C}-\mathrm{O}-\mathrm{C})$ group } \\
\hline 1107,4 & \\
\hline 1153,8 & \multirow[t]{3}{*}{$v(\mathrm{C}-\mathrm{H})$ in carbohydrates or / and $v(\mathrm{C}-\mathrm{O})$ in carbohydrates } \\
\hline 1209 & \\
\hline 1249 & \\
\hline 1331,3 & \multirow[t]{2}{*}{$\delta(-\mathrm{OH})$ in the $(\mathrm{C}-\mathrm{OH})$ group } \\
\hline 1373,2 & \\
\hline 1424 & $\delta(\mathrm{O}-\mathrm{H})$ in the $(\mathrm{C}-\mathrm{OH})$ group and $\delta(\mathrm{C}-\mathrm{H})$ in alkene \\
\hline
\end{tabular}




\begin{tabular}{|c|c|}
\hline 1643,3 & $v(\mathrm{C}=\mathrm{O})$ or $v(\mathrm{C}=\mathrm{C})$ from polyphenols $[52,53]$ \\
\hline 2902,4 & \multirow[t]{3}{*}{$v(\mathrm{C}-\mathrm{H}), v(\mathrm{O}-\mathrm{H})$ or/and $v(\mathrm{NH} 3)$ from free amino acids to carboxylic acids or polyphenols $[54,55]$} \\
\hline 2937 & \\
\hline 2972,2 & \\
\hline 3237,2 & $v(\mathrm{O}-\mathrm{H})$ polyphenols \\
\hline
\end{tabular}

$v$ - stretch vibrations, $\delta$ - deformation vibrations,

The intense signal was observed at $3237.2 \mathrm{~cm}^{-1}$ where a very large absorption band, characteristic of the $\mathrm{O}-\mathrm{H}$ bonds, due to the presence of phenolic compounds, was highlighted. Tewari et al. (2005) and Matysek (2018) studied the FTIR fingerprints of several types of honey (buckwheat, clover, alfalfa, carrot, wildflower, orange blossom, sunflower) and found that the absorption band in the area of $3200 \mathrm{~cm}^{-1}$ is the largest for buckwheat, which reveals the highest amount of polyphenols. The FTIR spectral profile of buckwheat in this study is similar to that of buckwheat in Kędzierska-Matysek's study [48].

\section{Conclusions}

Phenolic compounds and antioxidant activity can be considered some important factors for honey quality and its functional properties.

Given the results obtained from the analysis of polyphenolic compounds for buckwheat honey used in this research, it is possible to notice that the differences in the content of polyphenols and flavonoids, depending on the geographical area and the floral source.

The results of the study contribute to the knowledge of the major composition of phenolic compounds from buckwheat honey from the Balti region, Republic of Moldova and allow comparison with other honey samples from other countries. Thus, the buckwheat honey from our study is highlighted by much higher amounts of flavonoids compared to phenolic acids. There are high concentrations of GCG, EGC, isorhamnetin.

These determinations made on buckwheat honey from the Republic of Moldova offer opportunities for its use both as a main ingredient in many pharmaceutical and cosmetic preparations, as well as a valuable food for sustaining health.

Acknowledgements: The authors wish to thank "The Bioaliment Platform" from University "Dunarea de Jos" of Galati, for its technical support.

\section{References}

1.DUMITRIU-BUZIA, O., PlOSCUTANU, G., ELISEI, A, Tetracyclines Residues in Honey, Rev.Chim., 70(5), 2019, 1544-1550. https://doi.org/10.37358/RC.19.5.7166

2.BlaGA, G.,V., CHITESCU, L., C., LISA, E., L., DUMITRU, C., VIZIREANU, C., BORDA, D. Antifungal residues analysis in various Romanian honey samples analysis by high resolution mass spectrometry, J. Environ. Sci. Health, Part B, 2020, 1-11.

https://doi.org/10.1080/03601234.2020.1724016

3.BJORKMAN, T., BELLINDER, R., HAHN, R., SHAIL, J. Buckwheat Cover Crop Handbook, Cornell University Cooperative Extension, Geneva, NY, 2008,

http://www.hort.cornell.edu/bjorkman/lab/covercrops/pdf/bwbrochure.pdf

4.OPLINGER, E.S., OELKE, E., BRINKMAN, M.,A., KELLING, K.,A., Alternative Field Crops Manual:Buckwheat, Purdue University, West Lafayette, IN, 1989 Available at

https://hort.purdue.edu/newcrop/afcm/buckwheat.html

5.NAUMKIN, V.,P., Increase of productivity of nectar and yield of buckwheat via flower-nectar flow creation. In: Campbell C, Przybylski R (Eds) Current Advances in Buckwheat Research, Proceedings of the 7 th International Symposium on Buckwheat, Winnipeg, Manitoba, Canada, 12-14 August 1998. 
6.ALVAREZ-SUAREZ, J., TULIPANI S., DÍAZ, D. Antioxidant and antimicrobial capacity of several monofloral Cuban honeys and their correlation with color, polyphenol content and other chemical compounds. Food Chem. Toxicol. 48(8-9), 2010, 2490-2499.

https://doi.org/10.1016/j.fct.2010.06.021

7.ISLA M., CRAIG A., ORDÕNEZ, R., Physico chemical and bioactive properties of honeys from Northwestern Argentina. Lebensm. Wiss. Technol., 44(9), 2011, 1922-1930.

https://doi.org/10.1016/j.lwt.2011.04.003

8.VAN DEN BERG, A.,VAN DEN WORM, E., QUARLES, H., HALKES, S., HOEKSTRA, M., BEUKELMAN, C., An in vitro examination of the antioxidant and anti-infl ammatory properties of buckwheat honey, J Wound Care 7, (4), 2008, p. 172.

https://doi.org/10.12968/jowc.2008.17.4.28839

9.BRUDZYNSKI, K., ABUBAKER, K., WANG, T., Powerful bacterial killing by buckwheat honeys is concentration-dependent, Front.microbiol, 3(242), 2012, 1-9.

https://doi.org/10.3389/fmicb.2012.00242

10.HAMMOND, E., N., DUSTER, M., MUSUUZA, J., S., SAFDAR, N., Effect of United States buckwheat honey on antibiotic-resistant hospital acquired pathogens, PAMJ. 2016; 25:212, https://doi.10.11604/pamj.2016.25.212.10414

11.JIBRIL, F., I., HILMI, A., B., MANIVANNAN, L., Isolation and characterization of polyphenols in natural honey for the treatment of human diseases, $B N R C, \mathbf{4 3}(4), 2019,1-9$.

https://doi.org/10.1186/s42269-019-0044-7

12.GANESHPURKAR, A., SAlUJA, K., The Pharmacological Potential of Rutin. Saudi Pharm. J. 25(2), 2017, 149-164. https://doi.org/10.1016/j.jsps.2016.04.025

13.GIMENEZ-BASTIDA, J., A., ZIELINSKI, H., Buckwheat as a Functional Food and Its Effects on Health, J. Agric. Food Chem., 63, 2015, 7896-7913, https://doi.org/10.1021/acs.jafc.5b02498

14.TAHIR, H. E., ZOU, X., SHEN, T., SHI, J., MARIOD, A. A., Near-Infrared (NIR) spectroscopy for rapid measurement of antioxidant properties and discrimination of Sudanese honeys from different botanical origin, Food Anal. Methods, 9(9), 2019, 2631-2641. http://dx.doi.org/10.1007/s12161-016$\underline{0453-2}$

15.ESCUREDO, O., CARMEN, S., M., SALVADOR, J., GONZÁLEZ-MARTÍN, M., Near infrared spectroscopy for prediction of antioxidant compounds in the honey. Food Chem., 141(4), 2013, 34093414. https://doi.org/10.1016/j.foodchem.2013.06.066

16.***ISO 14502-1: 2005. Determination of substances characteristic of green and black tea. Part 1: Content of total polyphenols in tea. Colorimetric method using Folin-Ciocalteu reagent

17.BOZIN, B., MIMICA-DUKICB, N., SAMOJLIKC, I., GORAND, A., IGIC, R.,. Phenolics as antioxidants in garlic (Allium sativum L., Alliaceae). Food Chem, 111, 2008, 925-929.

https://doi.org/10.1016/j.foodchem.2008.04.071

18.BRAND-WILLIAMS, W., CUVELIER, M., BERSET, C. Use of a Free Radical Method to Evaluate Antioxidant Activity, J. Food Sci. Technol., 28(1), 1995, 25-30

https://doi.org/10.1016/S0023-6438(95)80008-5

19.DENG, J., LIUA, R., LUA, Q., HAOA, P., XUA, A., ZHANGA, J., TANA, J., Biochemical properties, antibacterial and cellular antioxidant activities of buckwheat honey in comparison to manuka honey, Food Chem., 252, 2018, 243-249. https://doi.org/10.1016/j.foodchem.2018.01.115

20.ZHOU, J., LI, P., CHENG, N., GAO, H., WANG, B., WEI, Y., CAO, W., Protective effects of buckwheat honey on DNA damage induced by hydroxyl radicals, Food Chem. Toxicol., 50(8), 2012, 2766-2773. https://doi.org/10.1016/j.fct.2012.05.046

21.JASICKA-MISIAK, I., POLIWODA, A., DEREN', M., KAFARSKI, P., Phenolic compounds and abscisic acid as potential markers for the floral origin of two Polish unifloral honeys, Food Chem., 131(4), 2012, 1149-1156. https://doi.org/10.1016/j.foodchem.2011.09.083

22.WILCZYŃSKA, A., Phenolic content and antioxidant activity of different types of polish honey a short report, Pol. J. Food Nutr. Sci. 60 (4), 2010, 309-313. 
23.WIECZOREK, J. PIETRZAK, M., POMIANOWSKI, J., WIECZOREK, Z., Honey as a source of bioactive compounds Pol. J. Natur. Sc., 29 (3), 2014, 275-285.

24.OZBALCI, B., BOYACI, I.,H., TOPCU,A., KADILAR, C., TAMER, U., Rapid analysis of sugars in honey by processing Raman spectrum using chemometric methods and artificial neural networks, Food Chem., 136, 2013, 1444-1452. https://doi.org/10.1016/j.foodchem.2012.09.064

25.DZUGAN, M., TOMCZYK, M., SOWA, P., GRABEK-LEJKO, D., Antioxidant Activity as Biomarker of Honey Variety, Molecules, 23, 2018, 2069-2083;

https://dx.doi.org/10.3390\%2Fmolecules23082069

26.KHALAFI, R., AMIR, S., GOLI, H., BEHJATIAN, M., Characterization and Classification of Several Monofloral Iranian Honeys Based on Physicochemical Properties and Antioxidant Activity, Int. J. Food Prop, 19(5), 2016, 1065-1079, https://doi.org/10.1080/10942912.2015.1055360

27.ESCUREDO, O., SEIJO, M.C., FERNÁNDEZ-GONZÁLEZ, M., Descriptive Analysis of Rubus Honey from the North-West of Spain, Int. J.Food Sci Technol., 46(11), 2011, 2329-2336, doi: 10.1111/j.1365-2621.2011.02753.X

28.CHEUNG, Y., MEENU, M., YU, X., XU, B., Phenolic acids and flavonoids profiles of commercial honey from different floral sources and geographic sources, Int. J. Food Prop, 22 (1), 2019 290-308. https://doi.org/10.1080/10942912.2019.1579835

29.CAN Z, YILDIZ O, SAHIN H., TURUMTAY, E., A., SILICI, S., KOLAYLI, S., An investigation of Turkish honeys: their physico-chemical properties, antioxidant capacities and phenolic profiles. Food Chem., 180, 215, 133-147. https://doi.org/10.1016/j.foodchem.2015.02.024

30.DA SILVA, I., A., DA SILVA, T., M., CAMARA, C., A., QUEIROZ, N., MAGNANI, M., DE NOVAIS, J., S., SOLEDADE, L.,E, LIMA EDE, O., DE SOUZA, A.,L., DE SOUZA, A., G., Phenolic profile, antioxidant activity and palynological analysis of stingless bee honey from Amazonas, northern Brazil. Food Chem., 141(4), 2013, 3552-3558.

https://doi.org/10.1016/j.foodchem.2013.06.072

31.SUGITA-KONISHI, Y., HARA-KUDO, Y., AMANO, F., OKUBO, T., AOI, N., IWAKI, M., Epigallocatechin gallate and gallocatechin gallate in green tea catechins inhibit extracellular release of Vero toxin from enterohemorrhagic Escherichia coli O157:H7. Biochim. Biophys. Acta, 1472 (1-2), 1999, 42-50. https://doi.org/10.1016/s0304-4165(99)00102-6

32.MURAMATSU, K., FUKUYO, M., HARA, Y., Effect of green tea catechins on plasma cholesterol level in cholesterol-fed rats. J Nutr Sci Vitaminol, 32(6), 1986, 613-22.

https://doi.org/10.3177/jnsv.32.613

33.MATSUDA, H., CHISAKA, T., KUBOMURA, Y., YAMAHARA, J., SAWADA, T., FUJIMURA, H., KIMURA, H., Effects of crude drugs on experimental hypercholesterolemia. I. Tea and its active principles, J Ethnopharmacol., 17(3), 1986, 213-24. https://doi.org/10.1016/0378-8741(86)90138-8

34.YANG, T., KOO, M., Chinese green tea lowers cholesterol level through an increase in fecal lipid excretion, Life Sci. 2000;66(5):411-23. https://doi.org/10.1016/s0024-3205(99)00607-4

35.KANDAKUMAR, S., MANJU, V., Pharmacological Applications of Isorhamnetin: A Short Review, IJTSRD, 1, 2017, p. 672-678. https://doi.org/10.31142/ijtsrd2202

36.SCHMITT-SCHILLIG, S., SCHAFFER, S., WEBER, C., C., ECKERT, G., P., MÜLLER, W., E., Flavonoids and the aging brain, J Physiol Pharmacol., 56 (1), 2005, 23-36.

37.YAO, L., JIANG, Y., D’ARCY,B., SINGANUSONG, R., DATTA, N., CAFFIN, N., RAYMONT, K., Quantitative High-Performance Liquid Chromatography Analyses of Flavonoids in Australian Eucalyptus Honeys, J. Agric. Food Chem. 52, 2004, 210-214, https://doi.org/10.1021/jf034990u

38.SHI, H., HE, J., LI, X., HAN, J., WU, R., WANG, D., YANG, F., SUN, E. ). Isorhamnetin, the active constituent of a Chinese herb Hippophae rhamnoides $L$, is a potent suppressor of dendritic-cell maturation and trafficking,. Int. Immunopharmacol, 55, 216-222.

https://doi.org/10.1016/j.intimp.2017.12.014 
39.WANG, X., ZHONG, W., Isorhamnetin attenuates collagen-induced arthritis via modulating cytokines and oxidative stress in mice, Int. J. Clin. Exp. Med. 8 (9), 2015, 16536-16542. https://www.ncbi.nlm.nih.gov/pmc/articles/PMC4659069/

40.AHN, H., LEE, G., S., Isorhamnetin and hyperoside derived from water dropwort inhibits inflammasome activation, Phytomedicine, 24, 2017, 77-86.

https://doi.org/10.1016/j.phymed.2016.11.019

41.NGUYEN, H., PANYOYAI, N., KASAPIS, S., PANG, E., MANTRI, N., Honey and Its Role in Relieving Multiple Facets of Atherosclerosis. Nutrients, 11(1), 201, 167.

https://doi.org/10.3390/nu11010167

42.PASINI, F., GARDINI, S., MARCAZZAN, G. L., CABONI, M. F., Buckwheat honeys: screening of composition and properties, Food Chem., 141(3), 2013, 2802-2811.

https://doi.org/10.1016/j.foodchem.2013.05.102

43.KASSIM, M., ACHOUI, M., MUSTAFA, M., R., MOHD, M., A., YUSOFF, K., M., Ellagic acid, phenolic acids, and flavonoids in Malaysian honey extracts demonstrate in vitro antiinflammatory activity. Nutr Res, 30, 2010, 650-659. https://doi.org/10.1016/j.nutres.2010.08.008

44.LACHMAN, J., ORSÁK, M., HEJTMÁNKOVÁ, A., KOVAROVA, E., Evaluation of antioxidant activity and total phenolics of selected Czech honeys, LWT-Food Sci Technol., 43, 2010, 52-58. https://doi.org/10.1016/j.lwt.2009.06.008

45.CIUCURE, C., T., GEANA, E., I., Phenolic compounds profile and biochemical properties of honeys in relationship to the honey floral sources, Phytochem Analysis., 2019, 1-12.

https://doi.org/10.1002/pca.2831

46.JANG, Y., J., SON, H., J., AHN, J., JUNG, C., H., HA, T., Coumestrol modulates Akt and Wnt/ $\beta$ catenin signaling during the attenuation of adipogenesis, Food Funct., 7(12), 2016, 4984-4991. https://doi.org/10.1039/c6fo01127f

47.BRAJDES-DUMITRU, C., BAHRIM, G., DINICA, R., VIZIREANU, C., Phenolics composition and their biochemical stability confirmation by IN VITRO gastrointestinal conditions simulation, for a new functional fermented beverage based on sprouted buckwheat, ROM BIOTECH LETT, 18(6), 2013, 8832- 8842. http://www.rombio.eu/vol18nr6/12\%20Brajdes.pdf

48.KĘDZIERSKA-MATYSEK, M., MATWIJCZUK, A., FLOREK, M., BARŁOWSKA, J., WOLANCIUK, A., MATWIJCZUK, A., CHRUŚCIEL, E., WALKOWIAK, R., KARCZ, D., GŁADYSZEWSKA, B., Application of FTIR spectroscopy for analysis of the quality of honey, BIO Web of Conferences 10, 02008 (2018) Contemporary Research Trends in Agricultural Engineering, https://doi.org/10.1051/bioconf/20181002008

49.TEWARI, J., IRUDAYARAJ, M., Floral Classification of Honey Using Mid-Infrared Spectroscopy and Surface Acoustic Wave Based z-Nose Sensor, J. Agric. Food Chem., 53 (18), 2015, 6955-6966. https://doi.org/10.1021/jf050139z

50.STIRBESCU, N., , ION, R., M., RADU, A., TEODORESCU, S., BUCURICA, I., A., STIRBESCU, R., M., GEBA, R., DULAMA, I., D., Complex Analytical Investigations of Old Wax sealed Romanian Paper Documents, Rev.Chim., 69(7), 2018, 1608-1611.

https://doi.org/10.37358/RC.18.7.6380

51.PRESEROVA, J., RANC, V., MILDE, D., KUBISTOVA, V., STAVEK, J., Study of phenolic profile and antioxidant activity in selected Moravian wines during winemaking process by FT-IR spectroscopy., J. Food Sci.Technol., 52(10), 2015, 1-10. https://doi.org/10.1007/s13197-014-1644-8

52.MOT, A., SILAGHI-DUMITRESCU, R., SÂRBU, C., Rapid and effective evaluation of the antioxidant capacity of propolis extracts using DPPH bleaching kinetic profiles, FT-IR and UV-vis spectroscopic data, J Food Compost Anal, 24 (4-5), 2011, 516-522.

https://doi.org/10.1016/j.jfca.2010.11.006

53.ANJOS, O., CAMPOS, M. G., RUIZ, P. C.,ANTUNES, P. Application of FTIR-ATR spectroscopy to the quantification of sugar in honey, Food Chem., 169, 2015, 218-223.

https://doi.org/10.1016/j.foodchem.2014.07.138 
54.MOVASAGHI, Z., REHMAN, S., REHMAN, I., U., Fourier transform infrared (FTIR) spectroscopy of biological tissues, Appl. Spectrosc. Rev., 43(2), 2008, 134-179, https://doi.org/10.1080/05704920701829043

55.OLIVEIRA, R., MANCINI, M. C., SALlES DE OLIVEIRA, F., PASSOS, T.M., QUILTY, B., THIRÉ, R.M., MCGUINNESS, G.B., FTIR analysis and quantification of phenols and flavonoids of five commercially available plants extracts used in wound healing, Matéria, 21 (3), 2016, 767- 779, https://doi.org/10.1590/S1517-707620160003.0072

Manuscript received: 7.02 .2020 